\title{
Perancangan Perencanaan Pembelajaran Anak Usia Dini Melalui Sistem Informasi Berbasis Website
}

\author{
Ririn Hunafa Lestari ${ }^{\circledR} \bowtie$, Agus Sumitra ${ }^{2}$, Rita Nurunnisa ${ }^{3}$, Mia Fitriawati ${ }^{4}$ \\ Pendidikan Guru Pendidikan Anak Usia Dini, Institut Keguruan dan Ilmu Pendidikan \\ Siliwangi $(1,2,3)$ \\ Sistem Informasi, Universitas Komputer Indonesia (4) \\ DOI: $\underline{10.31004 / \text { obsesi.v5i2.770 }}$
}

\begin{abstract}
Abstrak
Saat ini, perencanaan pembelajaran merupakan suatu beban bagi pendidik pendidikan anak usia dini yang berdampak pada proses pelaksanaan pembelajaran. Maka dari itu, penelitian ini bertujuan untuk merancang perencanaan pembelajaran anak usia dini melalui teknologi informasi dan komunikasi melalui sistem informasi berbasis website. Educational Design Research (EDR) merupakan metode penelitian yang digunakan dalam merancang desain perencanaan pembelajaran melalui sistem informasi berbasis website. Kajian literatur dan wawancara kepada pendidik PAUD merupakan teknik pengumpulan data yang digunakan dalam penelitian ini dengan subjek penelitian pendidik PAUD di salah satu kecamatan di kota Bandung. Setelah diperoleh hasil data, teknik analisis data yang digunakan adalah analisis tematik dengan pendekatan kualitatif untuk mengetahui pertanyaan penelitian berkaitan dengan perencanaan pembelajaran pada pendidikan anak usia dini. Berdasarkan hasil penelitian yang dilakukan, perencanaan pembelajaran pada pendidikan anak usia dini yang terdiri dapat disusun melalui suatu sistem informasi berbasis website sebab melalui website perencanaan pembelajaran akan saling berkaitan antar tampilan.
\end{abstract}

Kata Kunci: perencanaan pembelajaran; sistem informasi; website; anak usia dini.

\begin{abstract}
Currently, learning planning is a burden for early childhood education educators which has an impact on the process of implementing learning. Therefore, this study aims to design early childhood learning planning through information and communication technology through website-based information systems. Educational Design Research (EDR) is a research method used in designing learning planning designs through website-based information systems. Literature review and interviews with early childhood educators are data collection techniques used in this study with the research subjects of early childhood educators in one of the districts in the city of Bandung. After obtaining the data results, the data analysis technique used is thematic analysis with a qualitative approach to find out research questions related to learning planning in early childhood education. Based on the results of the research conducted, learning planning in early childhood education which consists of it can be arranged through a website-based information system because through the learning planning website it will be interrelated between views.
\end{abstract}

Keywords: learning planning; information systems; website; early childhood

Copyright (c) 2020 Ririn Hunafa Lestari, Agus Sumitra, Rita Nurunnisa, Mia Fitriawati

$\triangle$ Corresponding author:

Email Address: ririnhunafa@ikipsiliwangi.ac.id (Bandung, Jawa Barat)

Received 2 October 2020, Accepted 7 November 2020, Published 19 November 2020 


\section{PENDAHULUAN}

Dalam menciptakan generasi yang berkualitas, diharapkan bahwa pendidikan harus diberikan sejak dini melalui jenjang pendidikan untuk anak usia dini atau jenjang Pendidikan Anak Usia Dini (PAUD). Ketika anak-anak berada pada usia dini yaitu usia 0-6 tahun, kemampuan-kemampuan seorang anak perlu dirangsang dengan baik, sehingga diperlukan rencana pembelajaran yang baik dan tepat. Kurikulum sebagai bentuk perencanaan pembelajaran menjabarkan tentang tujuan, materi, isi atau bahan pembelajaran serta metode pengajaran yang akan disampaikan guna mencapai tujuan Pendidikan (P. P. R. Indonesia, 2005; P. M. P. dan K. R. Indonesia, 2014). Pada kurikulum untuk Pendidikan Anak Usia Dini (PAUD) terdiri dari program tahunan, program semester (Prosem), Rencana Pelaksanaan Pembelajaran Mingguan (RPPM), Rencana Pelaksanaan Pembelajaran Harian (RPPH) dan penilaian (Fitri, Saparahayuningsih, \& Agustriana, 2017; P. M. P. dan K. R. Indonesia, 2014).

Dalam merencanakan pembelajaran, guru berperan penting sebab guru yang merencanakan, melaksanakan dan menilai kegiatan-kegiatan pembelajaran. Kurikulum PAUD yang saat ini digunakan adalah kurikulum PAUD tahun 2013 yang merupakan penyempurnaan dari kurikulum sebelumnya sehingga dibutuhkan waktu untuk menerapkannya, hal tersebut didukung dari Penelitian Rahelly (2018) guru masih belum memahami bagaimana merencanakan dan menyusun rancangan pembelajaran berdasarkan standar kurikulum serta sebagian besar guru PAUD bukan dari lulusan sarjana PAUD sehingga dibutuhkan waktu dalam memahami standar kurikulum.

Selain itu terdapat hambatan bagi pendidik dalam merencanakan pembelajaran. Hal ini diungkapkan oleh pernyataan Nadiem Makarim sebagai Menteri Pendidikan dan Kebudayaan terkait dengan rencana pelaksanaan pembelajaran (RPP) bahwa kompetensi yang harus dikuasai guru tidak akan meningkat jika masih adanya keterbatasan guru dalam menyelesaikan perencanaan pembelajaran sehingga guru terlalu fokus pada urusan administratif yang berdampak pada proses pelaksanaan pembelajaran yang memunculkan kemungkinan yang kurang dalam menstimulus kemampuan peserta didik (dalam Antara, 2019). Hal ini menjadi salah satu dasar dari empat pokok kebijakan pendidikan merdeka belajar dalam meningkatkan kualitas sumber daya manusia. Selain itu pembuatan dan penyusunan rencana pembelajaran dirasakan pendidik PAUD sebagai beban, walaupun peran guru sebagai administrator telah terlaksana akan tetapi penjelasan tersebut berbanding terbalik dengan hasil wawancara bahwa pendidik merasa terbebani dengan peran guru sebagai administrator yang berdampak pada kurang fokus pendidik dalam memainkan peran sebagai pelaksanaan pembelajaran (Pembelajaran/Pelaksana., 2015). Tidak hanya itu dalam penyusunan dan pembuatan perencanaan, pendidik membuat dan menyusun secara manual dengan memanfaatkan lembar kertas dan arsip yang memungkinkan data-data tersebut hilang dan rusak (Alpiandi, 2016).

Di era modern ini, seluruh masyarakat sedang memasuki milenium ketiga yang menghadapkan masyarakat untuk menguasai kemajuan teknologi (Ngafifi, 2014; Depdiknas, 2007) Semakin tinggi ilmu pengetahuan maka akal manusia dalam membuat dan memanfaatkan teknologi semakin tinggi. Teknologi yang dibuat dan dimanfaatkan secara positif bertujuan untuk memberikan banyak kemudahan sebagai inovasi dalam membantu aktivitas manusia (Ngafifi, 2014). Harapan masyarakat pada suatu negara ketika menguasai teknologi dapat menjadi bangsa yang unggul dan mampu bersaing (Ngafifi, 2014; Depdiknas, 2007).

Penguasaan teknologi dapat diimplementasikan pada salah satu bidang kehidupan manusia yaitu bidang pendidikan, sebab tujuan dari sistem pendidikan nasional adalah menyiapkan manusia yang berkualitas. Maksud kata "kualitas" pada kalimat tersebut agar pendidikan dapat dilihat dari penerapan rencana pembelajaran yang dibentuk dalam kurikulum sesuai dengan kebutuhan peserta didik, pendidik dan tenaga kependidikan sebagai komponen perencanaan, pelaksanaan dan penilaian, salah satunya dengan memanfaatkan teknologi yang sudah dikuasai (Cholik, 2017; Rohita, 2020). 
Semakin berkembangnya teknologi informasi dan komunikasi, maka individu perlu menguasainya. Begitu juga pada pendidik PAUD yang dituntut untuk mengikuti perkembangan teknologi sesuai dengan Peraturan Menteri Pendidikan dan Kebudayaan Nomor 137 tahun 2014 pada kompetensi pedagogic point E bahwa pendidik memanfaatkan teknologi, informasi dan komunikasi untuk kepentingan penyelenggaraan kegiatan pengembangan yang mendidik.

Salah satu negara yang sudah memanfaatkan teknologi informasi dan komunikasi dalam pendidikan anak usia dini adalah Australia dengan menciptakan sistem informasi berbasis website yang dinamai Kidsoft sebagai sarana orang tua, pendidik anak usia dini dan tim pengembang pemrograman dalam merawat dan mengasuh anak usia dini melalui manajemen perangkat lunak. Saat ini kidsoft dapat dilihat pada tampilan resmi website dan terdapat aplikasi yang dapat diunduh melalui handphone dan tab di playstore dan appstrore (The Kidsoft, 2020). Akan tetapi pemanfaatan teknologi dan informasi komunikasi seperti tampilan website saat ini lebih banyak digunakan oleh jenjang pendidikan lainnya seperti sekolah dasar, menengah pertama dan menengah atas seperti penelitian yang dilakukan oleh Dengen \& Khairina (2016) bahwa sistem informasi akademik berbasis website dilakukan di jenjang sekolah menengah pertama di kota Samarinda yang memanfaatkan teknologi informasi dan komunikasi melalui sistem informasi berbasis website yang memberikan informasi tentang laporan keaktifan siswa secara online dalam bentuk laporan tulis serta absensi siswa sehingga membantu guru dalam memberikan informasi lebih cepat dan berkualitas.

Bersumber pada beberapa hasil wawancara dan hasil analisis dari beberapa artikel, muncul ide dan pemikiran peneliti untuk mengembangkan suatu sistem berbasis teknologi informasi dan komunikasi (TIK) yang dapat dimanfaatkan oleh pendidik PAUD dikarenakan kemajuan TIK yang saat ini berkembang dengan pesat dan telah mempengaruhi bidang pendidikan, sehingga peneliti berencana merancang suatu rancangan untuk membantu dan mempermudah guru dalam membuat dan menyusun rancangan pembelajaran melalui TIK yaitu sistem informasi berbasis website. Sistem informasi yang dipilih adalah sistem informasi yang memberikan data berkaitan dengan data akademik salah satunya adalah kurikulum (Setiyawan, Purnama, \& Sukadi, 2013).

Berdasarkan permasalahan tersebut, peneliti berencana untuk memanfaatkan dan mengembangkan TIK melalui sistem informasi berbasis website dalam membuat dan menyusun perencanaan pembelajaran untuk pendidik PAUD yang berkaitan dengan program semester, rencana pelaksanaan pembelajaran mingguan (RPPM) dan rencana pelaksanaan pembelajaran Harian (RPPH). Rancangan sistem informasi merupakan rancangan yang akan dibuat sebab sistem informasi merupakan sistem yang mengumpulkan, memproses, menyimpan, dan melaksanakan informasi yang diberikan dengan tujuan untuk mengatur sebuah informasi secara tersusun dan mempermudah pengguna untuk menggunakannya jika melibatkan teknologi (Sutarman, 2012; Rikanita, 2017; Mulyanto, 2009). Sistem informasi yang akan dibuat designnya berupa sistem informasi berbasis website. Website atau nama lain World Wibe Web (WWW) adalah layanan yang terhubung komputer dan laptop dengan internet melalui web browser yang menampilkan informasi berupa teks, gambar diam datu gerak animasi, suara atau gabungan dari bentuk informasi tersebut yang bersifat statis maupun dinamis membentuk satu rangkaian bangunan yang saling terkait dihubungkan dengan jaringan-jaringan halaman (hyperlink) (Rikanita, 2017; Yulianto \& Atmaja, 2018).

Sesuai dengan pernyataan di atas, peneliti mengajukan pertanyaan yang berkaitan dengan, seperti apa sistem informasi berbasis website dalam menyusun dan membuat perencanaan pembelajaran untuk PAUD?. Berdasarkan pertanyaan Penelitian tersebut, tujuan dari penelitian ini untuk mengembangkan rancangan design dari sistem informasi berbasis website dalam membuat dan menyusun rencana pembelajaran pada pendidikan anak usia dini. 


\section{METODOLOGI}

Berdasarkan studi pendahuluan yang diperoleh dari beberapa kajian literatur dan wawancara kepada pendidik PAUD, maka penelitian menggunakan metode Educational Design Research (EDR) dimana metode ini menjelaskan tentang upaya dalam memecahkan suatu permasalahan dengan cara mendesain dan mengembangkan suatu desain baik dalam bentuk program, materi dan strategi pembelajaran dan pengajaran serta dapat berbentuk produk atau sistem (Lidinillah, 2011). Pada metode penelitian EDR, peneliti akan menggunakan model McKenney $\mathcal{E}$ Reeves (dalam Lidinillah, 2011) sebagai prosedur penelitian ini, yang terdiri dari 1) tahapan exploration and analysis dengan menganalisis masalah melalui studi pendahuluan dengan cara menganalisis beberapa kajian literatur dan wawancara kepada pendidik PAUD, 2) tahap design and construction, peneliti merancang dan mengembangkan desain kembali desain perencanaan pembelajaran yang telah dirancang oleh Fitriawati \& Lestari, (2018) 3) tahapan evalution and reflection, dimana desain yang sudah dirancang sebelumnya didiskusikan kembali dengan seorang programmer di salah satu perusahaan IT di Bandung terhadap rancangan yang sudah dirancang sebelumnya sehingga diperoleh hasil bahwa sistem informasi yang digunakan berbasis website dengan mempertimbangkan penggunaan yang mudah diakses oleh pendidik PAUD. Adapun bagan dari tahapan-tahapan penelitian dengan menggunakan model McKenney $\mathcal{E}$ Reeves (dalam Lidinillah, 2011)

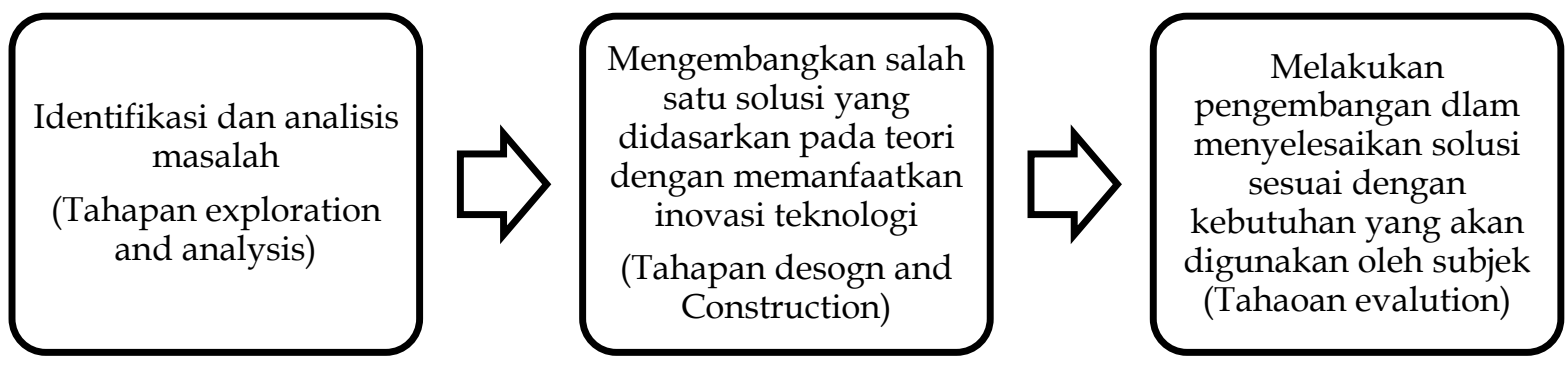

Bagan 1. Langkah-langkah Metode Penelitian EDR dengan Model McKenney \& Reeves

Sesuai dengan penjelasan di atas maka data penelitian dikumpulkan melalui kajian literatur beberapa artikel penelitian terkait dengan perencanaan pembelajaran sebagai studi pendahuluan. Selain kajian literatur data diambil dengan menggunakan teknik wawancara kepada pendidik PAUD dan programmer. Dalam merancang dan mendesain sistem informasi berbasis website, peneliti memilih pendidik PAUD di salah satu kecamatan di kota Bandung yang berjumlah 25 sebagai subjek penelitian ini dengan mempertimbangkan kebutuhan pendidik PAUD serta kemampuan pendidik dalam memanfaatkan TIK. Dari hasil data yang telah diperoleh, penelitian ini menggunakan pendekatan kualitatif yaitu teknik analisis data tematik yang menekankan pada jawaban-jawaban atas pertanyaan penelitian (Hancock \& Algozzine, 2006) dengan tujuan untuk mengembangkan teori-teori yang diperoleh dari menggabungkan kajian pada proses pembelajaran dengan berbagai aspek yang mendukung proses pembelajaran tersebut.

\section{HASIL DAN PEMBAHASAN}

Pada bagian hasil dan pembahasan dengan pendekatan analisis data grounded theory, dimana muncul tema baru yaitu penyusunan prosem, RPPM dan RPPH menggunakan sistem informasi berbasis website serta evaluasi diri Untuk pendidik. Adapun tahapan-tahapan yang akan dijelaskan sesuai tahapan model McKenney, S. \& Reeves (dalam Lidinillah, 2011) antara lain: 


\section{Tahap Eksploration dan Analysis}

pada tahapan ini peneliti menganalisis permasalahan tersebut dengan pendekatan analisis data tematik dimana pada analisis ini peneliti memperoleh hasil tema berdasarkan hasil wawancara,

"saya cape bu, hampir setiap hari saya fokus membuat RPPH dan RPPM dan sudah habis satu rim kertas untuk membuat RPPH dan RPPM dan itu semua (merajuk pada RPPH dan RPPM) belum tentu diacc bu sama bagian dinasnya." (hasil wawancara dengan pendidik PAUD di salah satu kota Cililin, 2019).

Hasil yang diperoleh selama wawancara yaitu pendidik masih membuat dan merancang perencanaan secara manual yang artinya pendidik memanfaatkan lembar kertas dan arsip yang memungkinkan data-data tersebut hilang dan rusak, hal ini sesuai dengan Penelitian yanh dilakukan oleh Alpiandi (2016) terhadap sistem informasi akademik berbasis web di SMP Negeri 2 Kecamatan Gaung Anak Serka.

Selain dari hasil wawancara, peneliti menganalisis beberapa kajian pustaka yang sesuai dengan pertanyaan penelitian, pendidik PAUD merasa terbebani dengan penyusunan dan pembuatan perencanaan pembelajaran sehingga tenaga dan pikiran yang pendidik lakukan terfokus pada perencanaan dan merasa kurang maksimal dalam merangsang perkembangan anak dan penilaian perkembangan anak. Hal ini sejalan dengan pernyataan yang dikemukakan oleh Menteri Pendidikan dan Kebudayaan Nadiem Makarim bahwa urusan administratif yang diurusi oleh pendidik PAUD memiliki dampak yang besar sehingga pendidik kurang dalam menstimulus seluruh aspek perkembangan anak pada saat proses pelaksanaan pembelajaran (Antara, 2019). Maka dari itu pada tabel 1 dijelaskan bahwa hasil wawancara dan hasil kajian literatur diperoleh tema dari hasil koding sebagai berikut:

Tabel 1. Kategorisasi Data Wawancara dan Kajian Literatur

\begin{tabular}{llll}
\hline \multicolumn{1}{c}{ Tema } & \multicolumn{1}{c}{ Sub Tema } & & \multicolumn{1}{c}{ Koding } \\
\hline Perencanaan & Peran guru & 1. & Arsip perencanaan pembelajaran \\
Pembelajaran & sebagai & 2. & Waktu dalam menstimulus perkembangan anak pada \\
PAUD & administrator & & proses pelaksanaan \\
& & 3. & Program Semester \\
& & 4. & Rencana Pelaksanaan Pembelajaran Mingguan (RPPM) \\
& 5. & Rencana Pelaksanaan Pembelajaran Harian (RPP) \\
\hline
\end{tabular}

\section{Tahap Design and Construction}

Pada tahapan ini peneliti melakukan pencarian berkaitan dengan perencanaan pembelajaran PAUD dan pemanfaatan TIK sehingga diperoleh hasil bahwa perencanaan pembelajaran khususnya di PAUD dirancang menggunakan scrum methdology yang dilakukan oleh Fitriawati \& Lestari (2018). Srum methdology merupakan pengembangan suatu sistem yang dimulai dari kemungkinan-kemungkinan adanya perubahan atau penambahan dalam proses pengembangan suatu proyek sehingga dibutuhkan metode pengembangan yang tanggap dalam menangani setiap perubahan dan menekankan pada proses iterasi yang menghasilkan produk berupa incremental product selama pengembangan berlangsung.

Dari Hasil yang diperoleh, peneliti melakukan diskusi dengan seorang programmer yang bekerja di salah satu perusahaan IT di kota Bandung berkaitan dengan isu-isu terhadap perencanaan pembelajaran PAUD dan pemanfaatan TIK yang saat ini berkembang dengan pesat dibidang pendidikan berdasarkan hasil penelitian yang dilakukan oleh (Fitriawati \& Lestari, 2018). Hasil diskusi tersebut diperoleh bahwa rancangan sistem informasi yang didesain dapat dirancang kembali menggunakan sistem informasi berbasis website dengan mempertimbangkan fungsi dan manfaat dari website. Pemanfaatan sistem informasi berbasis website dapat memberikan kemudahan dalam memberikan informasi dengan cepat agar 
kemampuan kinerja terhadap pelaksanaan dan penilaian pembelajaran dapat dilakukan dengan maksimal (Dengen \& Khairina, 2016)

Selain itu dilihat dari subjek penelitian yaitu pendidik PAUD, diharapkan fungsi dari website dapat membantu pendidik PAUD dalam memanfaatkannya sebab sistem informasi berbasis website banyak membutuhkan interaksi dari user selain menampilkan tampilan informasi dengan cepat yang dibuat dan direncanakan oleh guru PAUD untuk orang tua, kepala sekolah dan dinas pendidikan (Dengen \& Khairina, 2016; Gusriva, 2017; Cholik, 2017). Pemilihan peneliti dan programmer dalam memilih sistem informasi berbasis website dikarenakan tampilan dari website yang dapat digunakan di web browser di seluruh sistem operasi komputer dan smartphone (Hermawan, Hidayat, \& Utomo, 2016). Adapun penjelasan hasil dari analisis yang telah dilakukan pada tabel 2 dalam mengembangkan design.

Tabel 2. Kategorisasi Data Wawancara dan Kajian Literatur

\begin{tabular}{|c|c|c|}
\hline Tema & Sub Tema & Koding \\
\hline $\begin{array}{l}\text { Pengembangan TIK } \\
\text { di PAUD }\end{array}$ & Sistem Informasi & $\begin{array}{ll}\text { 1. } & \text { Pemanfaatan TIK } \\
\text { 2. } & \text { Pemanfaatan computer } \\
\text { 3. } & \text { Aplikasi browser } \\
\text { 4. } & \text { Website }\end{array}$ \\
\hline
\end{tabular}

\section{Tahap Evalution dan Reflection}

Dari tabel 1 dan 2 yang menjelaskan tema dari hasil koding pada tahapan eksploration dan analysis serta tahapan design and construction diperoleh tema perencanaan pembelajaran dapat dirancang melalui sistem informasi berbasis website. Diharapkan melalui rancangan ini, dapat meningkatkan kompetensi pedagogik guru dalam memanfaatkan teknologi informasi dan komunikasi dengan tujuan meningkatkan kualitas kegiatan pengembangan yang mendidik melalui TIK yang dimanfaatkan (P. M. P. dan K. R. Indonesia, 2014) sebab sistem informasi akademik berbasis web yang dilakukan oleh Dengen \& Khairina (2016) bahwa penggunaan website memberikan kemudahan dalam menginfomasikan pelaporan keaktifan siswa dengan cepat. Adapun proses pengkodean yang dilakukan selama wawancara dengan pendidik PAUD setelah menggunakannya yang dijelaskan pada tabel 3, sebagai berikut:

Tabel 3. Kategorisasi Data Wawancara

\begin{tabular}{|c|c|c|}
\hline Tema & Sub Tema & Koding \\
\hline $\begin{array}{l}\text { Pengembangan design } \\
\text { perencanaan pembelajaran } \\
\text { melalui sistem informasi } \\
\text { berbasis website }\end{array}$ & $\begin{array}{l}\text { Komponen perencanaan } \\
\text { pembelajaran PAUD } \\
\text { melalui sistem informasi } \\
\text { berbasis website }\end{array}$ & $\begin{array}{l}\text { 1. Program semester melalui sistem } \\
\text { informasi berbasis website. } \\
\text { 2. Rencana Pelaksanaan Pembelajaran } \\
\text { Mingguan (RPPM) melalui sistem } \\
\text { informasi berbasis website. } \\
\text { 3. Rencana Pelaksanaan Pembelajaran } \\
\text { Harian (RPPH) melalui sistem } \\
\text { informasi berbasis website. }\end{array}$ \\
\hline
\end{tabular}

Teknologi informasi dan komunikasi yang akan dibuat rancangannya adalah menggunakan sistem informasi berbasis website dalam membuat dan menyusun perencanaan pembelajaran PAUD yang terdiri dari program semester, rencana pelaksanaan pembelajaran mingguan (RPPM) dan rencana pelaksanaan pembelajaran Harian (RPPH) berdasarkan kurikulum 2013 sesuai dengan yang dijelaskan pada tabel 3. Adapun tampilan sistem informasi berbasis web yang telah dirancang sebagai pada gambar 1 . 


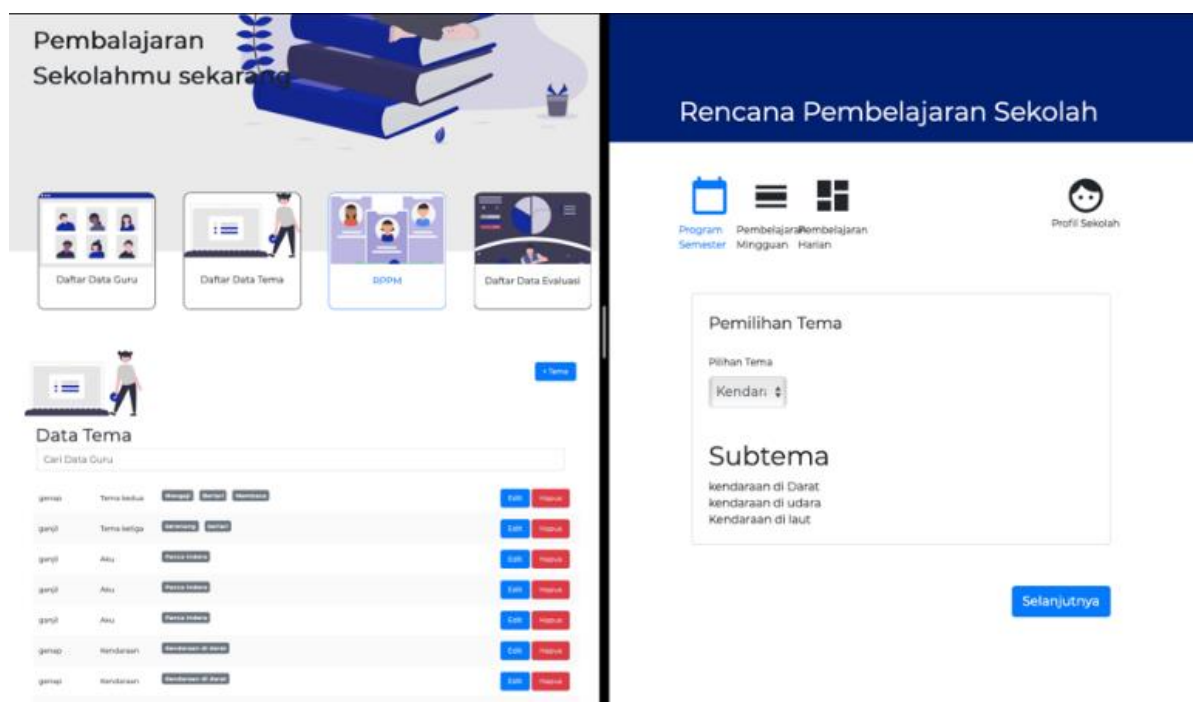

Gambar 1. Tampilan Penyusunan dan Pembuatan Program Semester

Pada saat pendidik mengakses website rencana pembelajaran sekolah, pendidik akan diminta untuk memiliki account terlebih dahulu. Setelah itu, pendidik akan diminta masuk melalui account yang sudah didaftarkan seperti pada gambar dua. Pendidik yang telah masuk akan ditampilkan tampilan penyusunan dan pembuatan program semester seperti pada gambar satu. Pada tampilan tersebut pendidik akan mengisi semester, tema, dan sub tema. Setelah itu dilanjutkan dengan mengisi kompetensi inti dan kompetensi dasar yang telah disediakan di web. Tidak hanya itu pendidik dapat berinovasi dan berkreasi dalam membuat tema dan sub tema baru, sehingga guru tidak terpaku kepada tema pada kurikulum 2013 PAUD Bahwa tema pembelajaran PAUD dibuat dengan memperhatikan empat tahapan dalam mengembangkan pembelajaran tematik yaitu kedekatan, kesederhanaan, kemenarikan dan keinsidentalan yang bersifat nyata disesuaikan dengan lingkungan sekolah, kebudayaan dan kepercayaan setempat (Nurdiana \& Sunarsih, 2016; Nurlailiyah, Aris \& Wartini, 2015).

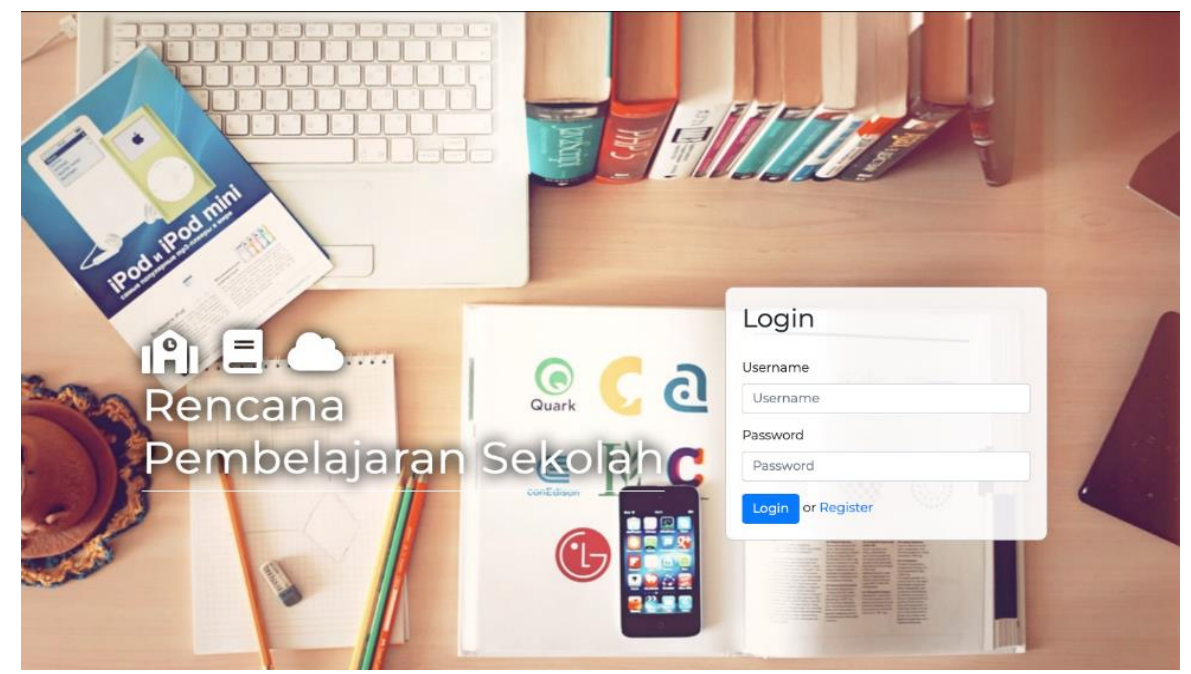

Gambar 2. Tampilan Log In Rencana Pembelajaran Berbasis Website

Setelah memilih dan mengisi semester, tema dan sub tema, pendidik akan ditampilkan pada gambar 3 untuk mengisi kompetensi inti dan kompetensi dasar dalam kurun waktu tertentu menyusun program semester. 


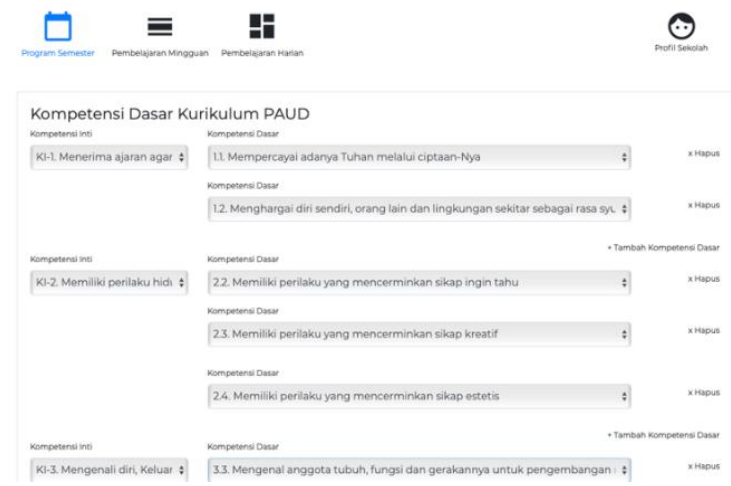

Gambar 3. Tampilan Pilihan Kompetensi Inti dan Dasar pada Program Semester

Jika pendidik sudah memilih pilihan pada tampilan program semester, pendidik dapat melanjutkan tampilan pembelajaran mingguan atau RPPM. Tampilan pertama pada gambar 4 yang harus diisi oleh pendidik adalah periode waktu dan tema untuk menentukan identitas program sebagai tahapan pertama dalam penyusunan RPPM (Nurdiana \& Sunarsih, 2016).

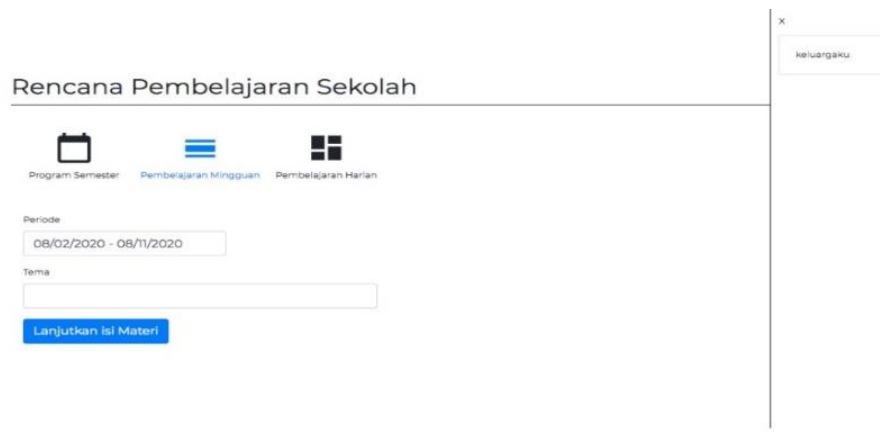

Gambar 4. Tampilan Pertama Pada Tampilan RPPM

Setelah diisi identitas program RPPM, hal selanjutnya yang perlu diisi adalah materi dan rencana kegiatan (gambar 5). Materi diambil dari kompetensi dasar yang sudah diisi sebelumnya pada program semester dan rencana kegiatan. Pada gambar lima terdapat perbedaan pengisian antara materi dan rencana kegiatan dimana pada rencana kegiatan, pendidik perlu mengisi sendiri rencana kegiatan tersebut yang kemudian akan disimpan langsung oleh sistem sehingga rencana kegiatan yang sudah dibuat oleh guru dapat dipilih lagi pada sub tema lain tanpa menuliskannya lagi.

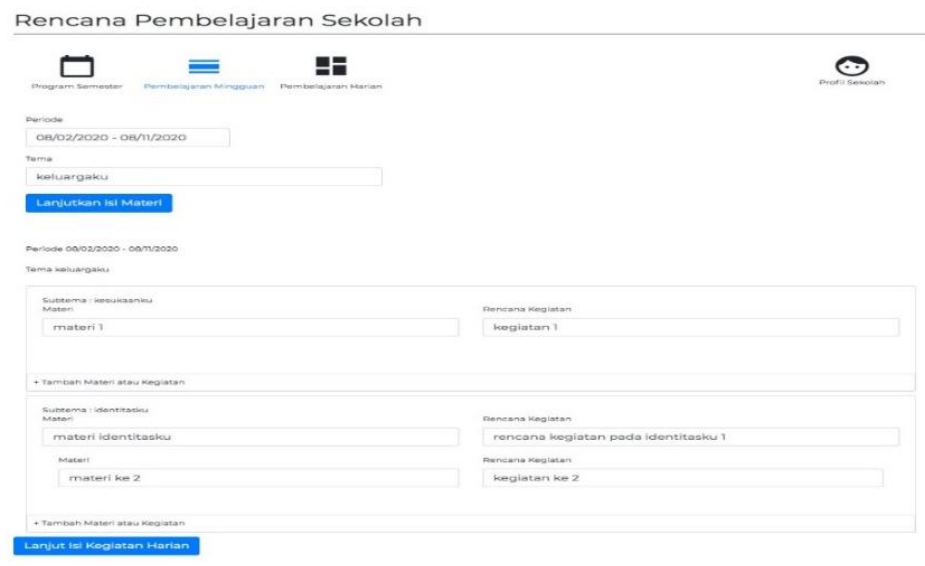

Gambar 5. Tampilan RPPM dalam Sistem Informasi Berbasis Website 
Setelah selesai dengan tampilan RPPM, pendidik dapat melanjutkan pada tampilan RPPH. Pada gambar 6, tampilan akan menampilkan kegiatan pembelajaran yang meliputi kegiatan-kegiatan pembelajaran seperti pembukaan, inti dan penutup, sesuai kebutuhan lembaga sekolah. Selain mengisi kegiatan pembelajaran, pendidik akan mengisi kegiatan rincian kegiatan, alat dan bahan serta memilik KD yang telah dipilih sebelumnya lalu mengisi indikator secara manual.

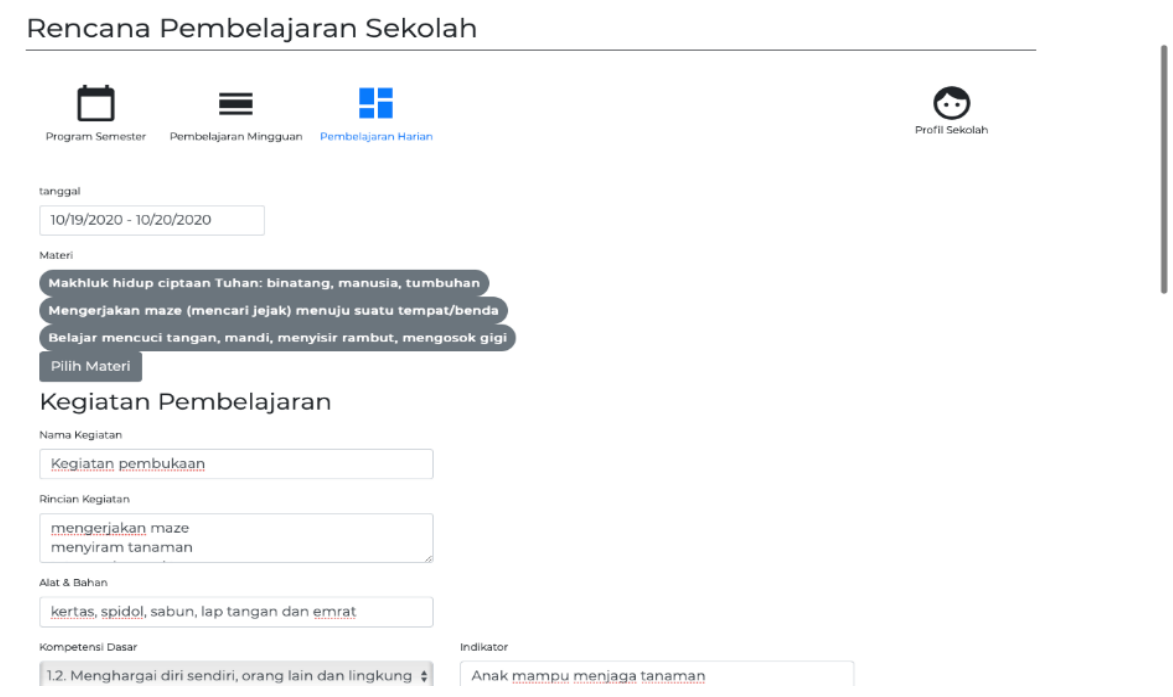

Gambar 6. Tampilan RPPH dalam Sistem Informasi Berbasis Website

Pada gambar 7 dan 8, jika sudah diisi semuanya, maka akan muncul tampilan akhir program semester, RPPM dan RPPH.

\section{Program Semester ganjil}

\begin{tabular}{|c|c|c|c|c|}
\hline No. & Tema & Subtema & KD & Waktu \\
\hline 1 & diriku & $\begin{array}{l}\text { 1. } \\
\text { identitasku } \\
\text { 2. tubuhku } \\
\text { 3. } \\
\text { kesukaanku }\end{array}$ & $\begin{array}{l}\text { 1.1.2. Menghargai diri sendiri, orang lain dan lingkungan sekitar sebagai rasa syukur kepada Tuhan } \\
\text { 1.21. Memiliki perilaku yang mencerminkann hidup sehat } \\
\text { 2.2.6. Memiliki perilaku yang mencerminkan sikap taat terhadap aturan sehari-hari untuk melatih kedisiplinan } \\
\text { 1.3.3. Mengenal anggota tubuh, fungsi dan gerakannya untuk pengembangan motorik kasar dan motorik halus } \\
\text { 2.3.5. Mengetahui cara memecahkan masalah sehari-hari dan berperilaku kratif } \\
\text { 1.4.4. Mampu menolong diri sendiri untuk hidup sehat } \\
\text { 2.4.7. Menyajikan berbagai karya yang berhubungan dengan lingkungan sosial (keluarga, teman, tempat tinggal, tempat ibadah, budaya, } \\
\text { tranportasi) dalam bentuk gambar, bercerita, bernyanyi dan gerak tubuh } \\
\text { 3. 4.10. Menunjukkan kemampuan berbaha reseptif (menyimak dan membaca) }\end{array}$ & \\
\hline
\end{tabular}

Rencana Pelaksanaan Pembelajaran Mingguan (RPPM) Periode: 10/18/2020 - 10/22/2020

\begin{tabular}{|c|c|c|c|}
\hline No. & Sub Tema & Materi & Rencana Kegiatan \\
\hline 1 & identitasku & $\begin{array}{l}\text { 1. Makhluk hidup ciptaan Tuhan: binatang, manusia, tumbuhan } \\
\text { 2. Menyayangi diri sendiri } \\
\text { 3. Kelestarian lingkungan } \\
\text { 4. Berolahraga } \\
\text { 5. Makan yang teratur }\end{array}$ & $\begin{array}{l}\text { 1. Menyebutkan anggota tubuh } \\
\text { 2. menggosok gigi } \\
\text { 3. melaksanakan jumat bersih } \\
\text { 4. melakukan senam irama } \\
\text { 5. Mencicipi masakan capcay }\end{array}$ \\
\hline 2 & tubuhku & $\begin{array}{l}\text { 1. Koordinasikan motorik halus } \\
\text { 2. Mengerjakan maze (mencari jejak) menuju suatu tempat/benda } \\
\text { 3. Praktek buang air kecil dan besar } \\
\text { 4. Belajar mencuci tangan, mandi, menyisir rambut, mengosok gigi } \\
\text { 5. Memelihara tanaman }\end{array}$ & $\begin{array}{l}\text { 1. Menjahit gambar baju } \\
\text { 2. mencari jejak } \\
\text { 3. Tollet traning } \\
\text { 4. tata cara mencuci tangan } \\
\text { 5. menyirami tanaman di halaman }\end{array}$ \\
\hline 3 & kesukaanku & $\begin{array}{l}\text { 1. Lagu anak-anak } \\
\text { 2. Keberanian dalam melakukan aktifitas } \\
\text { 3. Makanan ku } \\
\text { 4. Cambar cerita } \\
\text { 5. Tanya jawab tentang keterangan /informasi }\end{array}$ & $\begin{array}{l}\text { 1. menyanyikan lagu anak-anak } \\
\text { 2. berani mencoba sayuran dan buah } \\
\text { 3. membuat makanan kesukaan dari play dough } \\
\text { 4. mendengarkan cerita } \\
\text { 5. diskusi tentang makanan dan minuman kesukaan }\end{array}$ \\
\hline
\end{tabular}

Gambar 7. Tampilan Akhir untuk Program Semester dan RPPM 


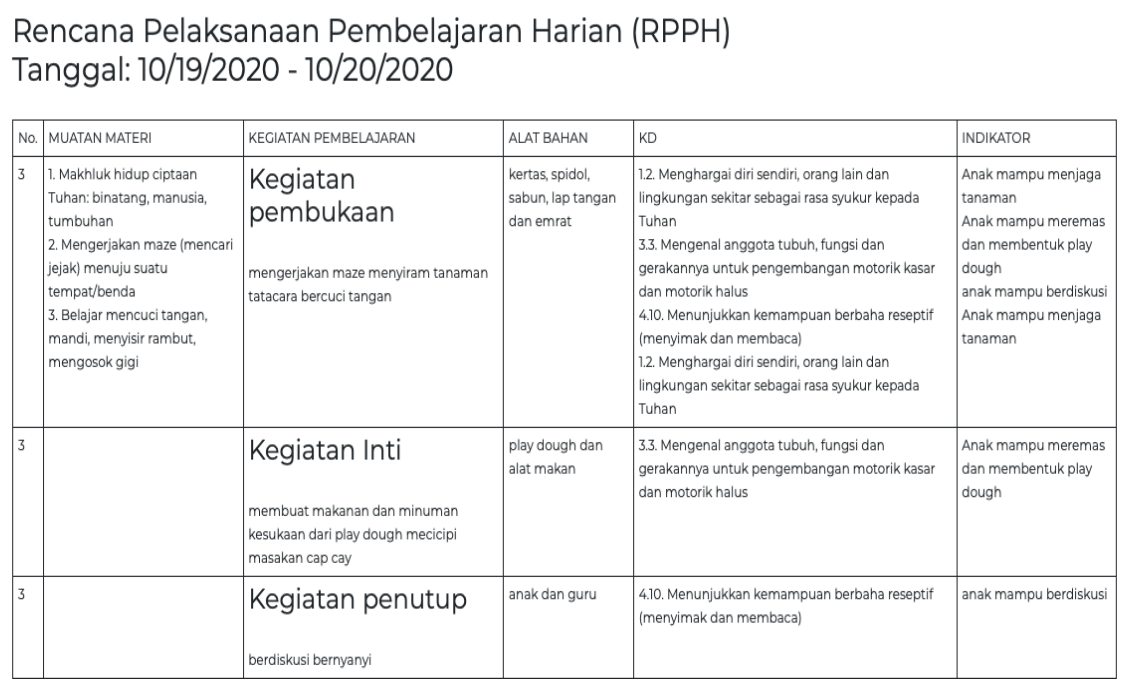

Gambar 8. Tampilan Akhir untuk RPPH

Dalam merancang perencanaan pembelajaran di PAUD, peneliti melakukan konsultasi kepada salah satu programmer sebagai ahli dalam merancang desain website sesuai dengan kebutuhan oleh klien agar sesuai dengan kebutuhan (Chow, Bridges, \& Commander, 2014). Maka dari itu peneliti melakukan konsultasi selama lima bulan dimulai dari bulan April 2020 sampai bulan Agustus 2020 dengan merencanakan alur pengguna masuk ke dalam tampilan website hingga diperoleh hasil dalam bentuk data yang siap digunakan. Selain itu pemanfaatan sistem informasi berbasis website merupakan salah satu perkembangan teknologi yang kian tumbuh berkembang di kalangan masyarakat Indonesia sebagai inovasi yang dapat dijangkau oleh Sebagian besar pendidik PAUD (Indriasari, 2012; Manzoor, Hussain, Ahmed, \& Iqbal, 2012)

Perancangan pembelajaran berbasis website dalam membuat dan menyusun program semester, RPPM dan RPPH di satuan tingkat pendidikan PAUD diperoleh hasil bahwa dari hasil wawancara dengan pendidik PAUD setelah menggunakan rancangan tersebut, pendidik terbantu dalam penggunaannya sebab tidak menghabiskan waktu lama dalam pembuatan dan penyusunannya. Hal ini disesuaikan dengan penelitian yang dilakukan oleh Rohita (2020) bahwa pendidik PAUD dapat menyusun perencanaan, pelaksanaan dan penilaian melalui TIK sesuai dengan kompetensi pedagogic pendidik PAUD (Sum \& Taran, 2020). Salah satu TIK yang dapat digunakan adalah sistem informasi berbasis website bahwa membantu dan memudahkan pendidik dalam mengelola data baik data pendidik, peserta didik, jadwal pembelajaran serta materi pembelajaran dalam proses belajar mengajar yang dapat diakses dimanapun dan kapanpun Fadlilah (2015; Desy \& Setyoko, 2017).

Pada proses pengelolaan perencanaan pembelajaran melalui sistem informasi berbasis website akan ditampilkan berbagai macam informasi dan membentuk suatu rangkaian yang saling keterkaitan dan dihubungkan dengan menggunakan alamat url (Maulana, 2008; Noviana, Kurniaman, \& Huda, 2018). Berdasarkan hal tersebut, dalam tampilan tersebut diperoleh bahwa guru menyusun dan membuat rencana pembelajaran untuk kurun waktu semester dilanjutkan kepada mingguan dan diakhiri dengan harian yang saling berkaitan dalam satu alamat url, penyusun tersebut menggunakan system navigasi click and go bahwa cara penggunaannya dengan memberi input pilihan dan diproses menuju tampilan selanjutnya yang ingin dituju (Fakhruddin et al., 2019; Choi \& Bakken, 2010; Štefko, Fedorko, \& Bačík, 2016). Tampilan website yang telah dibuat dan disusun didasari dari pengalaman pengguna terhadap praktik yang diciptakan agar solusi yang ditawarkan dapat dimanfaatkan secara efisien dan menarik khususnya untuk pendidik PAUD dalam memanfaatkan TIK (Chow et al., 2014; Aziz, Wan Mohd Isa, \& Nordin, 2010). 


\section{SIMPULAN}

Perancangan pembelajaran pada PAUD dapat dibuat dan dirancang dengan menggunakan sistem informasi berbasis website di PAUD sebagai temuan baru dalam memanfaatkan TIK yang ditujukan oleh pendidik dalam memahami pemanfaatan TIK. Selain itu pendidik PAUD terbantu dengan adanya sistem informasi berbasis website dalam membuat dan menyusun perencanaan pembelajaran, sebab pendidik lebih mudah dalam penggunaannya dan menjadi inovasi dalam perencanaan pembelajaran PAUD. Maka dari itu perencanaan pembelajaran di PAUD dapat dibuat dan disusun dalam bentuk website berdasarkan sistem informasi yang efisien dalam penggunaannya, dikarenakan melalui website keterkaitan antara program semester, RPPM dan RPPH lebih efektif digunakan.

\section{UCAPAN TERIMA KASIH}

Pada penelitian, peneliti ingin mengucapkan terima kasih kepada Direktorat Jenderal Pendidikan Tinggi Menteri Pendidikan dan Kebudayaan Republik Indonesia yang telah memberikan kesempatan kepada peneliti dalam mengembangkan penelitian ini dan kepada Institut Keguruan dan Ilmu Pendidikan (IKIP) Siliwangi, Fakultas Ilmu Pendidikan, Program Studi Pendidikan Guru Pendidikan Anak Usia Dini (PG-PAUD) yang telah memberikan kesempatan kepada peneliti. (Novtiar \& Aripin, 2017)

\section{DAFTAR PUSTAKA}

Alpiandi, R. M. (2016). Sistem Informasi Akademik Berbasis Web Di Smp Negeri 2 Kecamatan Gaung Anak Serka. Jurnal Sistemasi Sistem Informasi, 5(3), 8-13. https:// doi.org/https:// doi.org/10.32520/stmsi.v5i3.29

Antara, A. (2019). Nadiem: Kualitas Guru Sulit Naik Jika Terbebani Administrasi.

Aziz, M. A., Wan Mohd Isa, W. A. R., \& Nordin, N. (2010). Assessing the accessibility and usability of Malaysia higher education website. Proceedings - 2010 International Conference on User Science and Engineering, i-USEr 2010, 3(2008), 203-208. https:// doi.org/10.1109/IUSER.2010.5716752

Choi, J., \& Bakken, S. (2010). Web-based education for low-literate parents in Neonatal Intensive Care Unit: Development of a website and heuristic evaluation and usability testing. International Journal of Medical Informatics, 79(8), 565-575. https:// doi.org/10.1016/j.ijmedinf.2010.05.001

Cholik, C. A. (2017). Pemanfaatan Teknologi Informasi Dan Komunikasi Untuk Meningkatkan Pendidikan Di Indonesia. Syntax Literate; Jurnal Ilmiah Indonesia, 2(6), 21-30.

Chow, A. S., Bridges, M., \& Commander, P. (2014). The website design and usability of US academic and public libraries: Findings from a nationwide study. Reference and User Services Quarterly, 53(3), 253-265. https:// doi.org/10.5860/rusq.53n3.253

Dengen, N., \& Khairina, D. M. (2016). Sistem Informasi Akademik Berbasis Web SMP Negeri 4 Samarinda. Informatika Mulawarman: Jurnal Ilmiah Ilmu Komputer, 4(2), 18-29.

Depdiknas, P. K.-B. (2007). Kerangka Dasar Kurikulum Pendidikan Anak Usia Dini.

Desy, R., \& Setyoko, S. (2017). Pengembangan Pembelajaran Blended Learning Berbasis Website Di Program Studi Pendidikan Biologi Universitas Samudra. Jurnal Pendidikan Biologi, 6(3), 346-350. https:// doi.org/10.24114/jpb.v6i3.7902

Fadlilah, U. (2015). Rancang Bangun Website dan E-Learning di TPQ Al-Fadhillah. Khazanah Informatika: Jurnal Ilmu Komputer Dan Informatika, 1(1), 40. https:// doi.org/10.23917/khif.v1i1.1181

Fakhruddin, D., Sachari, A., \& Haswanto, N. (2019). Pengembangan Desain Informasi dan Pembelajaran Aksara Jawa melalui Media Website. ANDHARUPA: Jurnal Desain $\begin{array}{lllll}\text { Komunikasi Visual } \quad \mathcal{E} \text { Multimedia, } & \text { 5(01), }\end{array}$ https:// doi.org/10.33633/andharupa.v5i01.1990

Fitri, A. E., Saparahayuningsih, S., \& Agustriana, N. (2017). Perencanaan Pembelajaran 
DOI: 10.31004/obsesi.v5i2.770

Kurikulum 2013 Pendidikan Anak Usia Dini (Penelitian Deskriptif Kuantitatif Di Paud IT Auladuna Kota Bengkulu). Jurnal Ilmiah Potensia, 2(1), 1-13. https://doi.org/https://doi.org/10.33369/jip.2.1.1-13

Fitriawati, M., \& Lestari, R. H. (2018). Design of the Information System for Kindergarten Learning Plan used Scrum Methodology. IOP Conference Series: Materials Science and Engineering, 407(1). https:/ / doi.org/10.1088/1757-899X/407/1/012131

Gusriva, R. (2017). Pada Website Rencana Pengembangan. Jurnal KomTekInfo, 4(2), 204-213.

Hancock, D. R., \& Algozzine, B. (2006). Doing Case Study Research: A Pratical Guide for Beginning Researches. New York and London: Teacher College Columbia University.

Hermawan, R., Hidayat, A., \& Utomo, V. G. (2016). Sistem Informasi Penjadwalan Kegiatan Belajar Mengajar Berbasis Web (Studi Kasus : Yayasan Ganesha Operation Semarang). EVOLUSI: Jurnal Sains Dan Manajemen, 4(1), 72-79. https://doi.org/10.1017/CBO9781107415324.004

Indonesia, P. M. P. dan K. R. Peraturan Menteri Pendidikan dan Kebudayaan Republik Indonesia Nomor 137 tentang Standar Nasional Pendidikan Anak Usia Dini. , (2014).

Indonesia, P. P. R. Peraturan Pemerintah Republik Indonesia tentang Standar Nasional Pendidikan. , (2005).

Indriasari, S. (2012). Sistem Informasi Berbasis Web untuk Membantu Kegiatan Tracer Study Program Diploma Institut Pertanian Bogor. Jurnal Sains Terapan, 2(1), 48-58. https:// doi.org/10.1017/CBO9781107415324.004

Lidinillah, D. A. M. (2011). Educational design research : a theoretical framework for action. Jurnal UPI, (1), Bandung: Tidak Diterbitkan.

Manzoor, M., Hussain, W., Ahmed, A., \& Iqbal, M. J. (2012). The importance of Higher Education Website and its Usability. International Journal of Basic and Applied Sciences, 1(2), 150-163. https:// doi.org/10.14419/ijbas.v1i2.73

Maulana, I. (2008). Analisis dan Perancangan Sistem Informasi Berbasis Websitepada SMA Negeri 1 Pemalang. Sekolah Tinggi Manajemen Informatika dan Komputer.

Mulyanto. (2009). Sistem Informasi Konsep dan Aplikasi. Yogjakarta: Pustaka Pelajar.

Ngafifi, M. (2014). Kemajuan Teknologi Dan Pola Hidup Manusia Dalam Perspektif Sosial Budaya. Jurnal Pembangunan Pendidikan: Fondasi Dan Aplikasi, 2(1), 33-47. https://doi.org/10.21831/jppfa.v2i1.2616

Noviana, E., Kurniaman, O., \& Huda, M. N. (2018). Pengembangan Aplikasi Bimbingan Tugas Akhir Mahasiswa Berbasis Website Pada Program Studi Pendidikan Guru Sekolah Dasar Fkip Universitas Riau. Primary: Jurnal Pendidikan Guru Sekolah Dasar, 7(1), 1. https://doi.org/10.33578/jpfkip.v7i1.5334

Novtiar, C., \& Aripin, U. (2017). Dan Kepercayaan Diri Siswa Smp Melalui. VI(2), 119-131.

Nurdiana, J., \& Sunarsih. (2016). Modul Guru Pembelajar Taman Kanak-kanak Kelompok Kompetensi C. Bandung: Pusat Pengembangan dan Pemberdayaan Pendidik dan Tenaga Kependidikan Taman Kanak-Kanak dan Pendidikan Luar Biasa Direktorat Guru dan Tenaga Kependidikan.

Nurlailiyah, Aris \& Wartini, A. (2015). Kebijakan Pembelajaran Tematik Integratif Dalam $\begin{array}{llll}\text { Kurikulum } & 2013 & \text { Paud. } & \text { 47-70. }\end{array}$ https://doi.org/https://doi.org/10.28944/afkar.v3i1.99

Pembelajaran/Pelaksana., 6 Peran guru PAUD dalam Proses. (2015). 6 Peran guru PAUD dalam Proses Pembelajaran/Pelaksana.

Rahelly, Y. (2018). Implementasi Kurikulum 2013 Pendidikan Anak Usia Dini (Paud) Di Sumatera Selatan. JPUD - Jurnal Pendidikan Usia Dini, 12(2), 381-390. https://doi.org/10.21009/jpud.122.21

Rikanita. (2017). Pengembangan Sistem Informasi Sekolah Berbasis Website di SMK Negeri 1 Makassar. Universitas Negeri Makasar.

Rohita. (2020). The Ability of Ece Teachers To Use ICT in The Industrial Abstrak. Jurnal Obsesi : Jurnal Pendidikan Anak Usia Dini, 4(2), 502-511. 
https:// doi.org/10.31004/obsesi.v4i1.339

Setiyawan, A., Purnama, B. E., \& Sukadi. (2013). Pembuatan Sistem Informasi Akademik Berbasis Web Pada Sekolah Menengah Atas Negeri 1 Ngadirojo. Sistem Informasi Akademik Berbasis Web, 3, 1-5.

Štefko, R., Fedorko, R., \& Bačík, R. (2016). Website Content Quality In Terms Of Perceived Image Of Higher Education Institution. Polish Journal of Management Studies, 13(2), 153 163. https://doi.org/10.17512/pjms.2016.13.2.15

Sum, T. A., \& Taran, E. G. M. (2020). Kompetensi Pedagogik Guru PAUD dalam Perencanaan dan Pelaksanaan Pembelajaran. Jurnal Obsesi: Jurnal Pendidikan Anak Usia Dini, 4(2), 543. https:// doi.org/10.31004/obsesi.v4i2.287

Sutarman. (2012). Buku Pengantar Teknologi Informasi. Jakarta: Bumi Aksara.

The Kidsoft, T. (2020). Kidsoft.

Yulianto, S. V., \& Atmaja, A. P. (2018). Rancang Bangun Sistem Informasi Kurikulum 2013 Tingkat Sekolah Dasar Berbasis Web dengan SDLC Waterfall. Sisfo, 07(02), 149-164. https:// doi.org/10.24089/j.sisfo.2018.01.006 